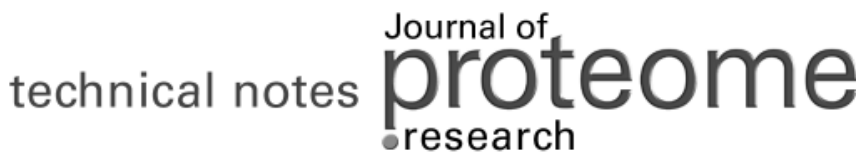

\section{On-Line Concentration of Microheterogeneous Proteins by Capillary Electrophoresis Using SDS and PEO as Additives}

\author{
Yu-Fen Huang, ${ }^{\dagger}$ Ming-Mu Hsieh, ${ }^{\ddagger}$ Wei-Lung Tseng, ${ }^{\dagger}$ and Huan-Tsung Chang ${ }^{*, \dagger}$ \\ Department of Chemistry, National Taiwan University, Taipei, Taiwan, and Department of Applied Chemistry, \\ Fooyin University, Kaohsiung, Taiwan
}

Received September 5, 2005

\begin{abstract}
In this paper, we describe a method for analyzing large-volume protein samples using capillary electrophoresis in conjunction with laser-induced fluorescence detection (CE-LIF). To improve the stacking and separation efficiencies of proteins, we added either $0.01 \%$ sodium dodecyl sulfate (SDS) or $0.01 \%$ poly (ethylene oxide) (PEO) to the Tris-borate solutions $(\mathrm{pH} 10.0)$ used to prepare the protein samples. After injection of the large-volume samples (ca. $1.0 \mu \mathrm{L}, 0.1 \mu \mathrm{M}$ ), the proteins migrate against the electroosmotic flow (EOF) and enter the PEO zone; this process causes them to slow and stack at the boundary between the PEO and sample zones. As a result, the limits of detection (LODs) at a signal-to-noise $(S / N)$ of 3 for most proteins are sub-nM to several nM. For instance, the $\operatorname{LOD}(S / N=3)$ for $\alpha$-lactalbumin is $0.48 \mathrm{nM}$, which is an 84-fold sensitivity enhancement over the traditional method. By applying a short plug of $0.2 \%$ SDS prior to sample injection, a greater number of peaks, representing the microheterogeneity of the proteins, were resolved and the stacking efficiency of the proteins increased slightly. This method allowed us to detect 12 peaks when injecting a large volume of sample containing six model proteins $(0.1 \mu \mathrm{M})$. We also analyzed the microheterogeneities of the proteins by using CE with UV-Vis absorption detection when injecting a large volume of sample containing six model proteins $(1.0 \mu \mathrm{M})$ in the presence of a $1.0 \%$ SDS plug. The practical method is validated by the detection of human serum albumin in a urine sample, obtained from a healthy female, without sample pretreatment; its concentration was $0.18 \mu \mathrm{M}$. We further demonstrate the capability of this method to detect low amounts of proteins through the detection of $45 \mathrm{nM}$ hemoglobin after injecting ca. $1.0 \mu \mathrm{L}$ of ultradilute lysed red blood cells. The experimental results indicate that our proposed method has great potential for use in diagnosis and proteomics applications.
\end{abstract}

\footnotetext{
* To whom correspondence should be addressed. Tel/Fax: 011-886-233661171. E-mail: changht@ntu.edu.tw.

${ }^{\dagger}$ National Taiwan University.

${ }^{\ddagger}$ Fooyin University.

Keywords: capillary electrophoresis • on-line concentration • poly(ethylene oxide) • sodium dodecyl sulfate $\bullet$ urine $\bullet$ red blood cell lysate

\section{Introduction}

The determination of proteins in biological samples is of great importance in fundamental research, pharmacokinetics, and drug monitoring, and for toxicological control. ${ }^{1-3}$ Because of the complicated nature of sample matrixes and, sometimes, the extremely low concentrations of the samples of interest, highly sensitive and efficient methods are needed for protein analysis. ${ }^{4,5}$ Capillary electrophoresis (CE), which provides the advantages of ease of automation, simplicity of operation, high speed, high separation efficiency, attomolar detection sensitivity, and low sample and reagent consumption, is well established as a practical and powerful tool for analyses of proteins. For example, CE has been applied to the analysis of proteins in single cells and in proteomics. ${ }^{6,7}$ One of the drawbacks of $\mathrm{CE}$, however, is its poor concentration detection limit, which arises from the short optical path length across the capillary and the small sample volumes that are injected. Laser-induced fluorescence (LIF) has become one of the most sensitive methods of detection for $\mathrm{CE},{ }^{8}$ but the derivatization of proteins is generally required. Although the use of CE-LIF in conjunction with a UV laser is an alternative for the analysis of proteins having intrinsic fluorescence, it is not as popular as UV-Vis absorption detection because of the high costs of UV lasers and their maintenance, the poor fluorescence quantum yields of proteins (tryptophan and tyrosine), and, sometimes, the fluorescence quenching caused by Joule heating, salt, and $\mathrm{pH}^{9,10}$

Several on-line concentration approaches have been developed to improve the sensitivity toward a wide number of analytes, including field-amplified sample stacking, isotachophoresis (ITP), and isoelectric focusing (IEF). ${ }^{11-21}$ The most common on-line concentration approaches for proteins are based on ITP and IEF. ${ }^{18-21}$ An on-line concentration approach based on $\mathrm{pH}$ junctions has been developed for CE for the analysis of trace proteins under acidic conditions. ${ }^{12}$ Stacking arises because of decreases in the electrophoretic mobilities of proteins when they migrate from the sample zone into a zone of relatively high-pH electrolyte in the capillary. This approach has been applied to the analyses of ca. 0.66 and 1.31 $\mu \mathrm{L}$ of 0.20 and $5.00 \mu \mathrm{M}$ tryptic and peptic digests of $\beta$-casein within 14 and $21 \mathrm{~min}$, respectively. The efficiency, concentration factor, and reproducibility of these methods, however, are 
Table 1. Chemical and Physical Properties of Proteins

\begin{tabular}{|c|c|c|c|c|c|c|}
\hline protein (source) & $M_{\mathrm{W}}$ & $\mathrm{p} I$ & $R^{a}(\mathrm{~nm})$ & $\begin{array}{c}\text { native } \\
\text { conformation }\end{array}$ & $\begin{array}{l}\text { hydrophobic } \\
\text { parameter }^{b}\end{array}$ & microheterogeneity \\
\hline CA (bovine erythrocytes) & 29000 & 6.2 & 2.05 & globular & 1000 & $5^{d}$ \\
\hline TI (soybean) & 21000 & 4.5 & 1.81 & globular & 1150 & $1^{e}$ \\
\hline$\alpha$-LAC (bovine milk) & 14200 & 4.7 & 1.59 & globular & 1050 & $2^{f}$ \\
\hline$\beta$ - CAS (bovine milk) & 23500 & 5.1 & 1.88 & fibrous & $\mathrm{NF}^{c}$ & $4^{g}$ \\
\hline OVA (chicken egg) & 45000 & 4.7 & 2.34 & globular & 980 & $13^{h}$ \\
\hline BSA (bovine plasma) & 66000 & 4.7 & 2.66 & globular & 1000 & $5^{i}$ \\
\hline
\end{tabular}

${ }^{a}$ Spherical radius, calculated by assuming that all the proteins are spherically shaped. The radii of these proteins were calculated from their volumes using the equation $r=(3 V / 4 \pi))^{1 / 3} .{ }^{b}$ ref 32. ${ }^{c}$ Not found. ${ }^{d}$ ref 33. ${ }^{e}$ ref 34. ${ }^{f}$ ref 35. ${ }^{g}$ ref 36. ${ }^{h}$ ref 37. ${ }^{i}$ ref 38.

usually strongly dependent on the nature of the sample matrixes. Recently, we developed on-line concentration techniques for the analyses of proteins by CE using poly(ethylene oxide) (PEO). ${ }^{10,22,23}$ In this process, after injecting a large volume of protein sample to a capillary filled with Tris-borate (TB) buffer, PEO (neutral) is introduced into the capillary under electroosmotic flow (EOF). Once the voltage is applied, proteins having negative charges migrate against the EOF and enter the PEO zone and become stacked as a result of a decrease in their electrophoretic mobility due to increases in the viscosity and sieving effects. For the analysis of proteins in urine samples, we have found that this method is effective for improving the stacking efficiency when a short, low-pH plug is injected after sample injection. ${ }^{22}$

CE analyses using polymer solutions or gels are commonly applied to the separation of proteins according to a sieving mechanism. ${ }^{24-26}$ Polymer solutions are preferred over crosslinked gels for a number of reasons, including their relatively low viscosity, ease of preparation, and flexibility. Polymer solutions that are used for the analysis of proteins are commonly prepared using linear polymers, including cellulose and its derivatives, linear poly(acrylamide) (LPA), PEO, and poly(vinyl alcohol) (PVA). ${ }^{24,26-29}$ To saturate protein charges, accelerate the separation, dissolve hydrophobic proteins, and/ or prevent aggregation of proteins during separation, anionic surfactants, such as sodium dodecyl sulfate (SDS), are commonly added to polymer solutions and samples. ${ }^{24,25,30}$ Unfortunately, SDS causes a high background signal and fluorescence quenching when protein analyses are conducted by $\mathrm{CE}$ in conjunction with laser-induced fluorescence (LIF) using a UV laser. Recently, we applied a segmental filling technique to CE to improve the separation efficiency while achieving high sensitivity during the analysis of the microheterogeneity of proteins. Without sample pretreatment, using a short plug (ca. $2.5 \mathrm{~cm}$ ) of $1.0 \%$ SDS, we resolved six $\alpha$-amylase isoforms in a salivary sample within $17 \mathrm{~min} .{ }^{27}$ Although this method solves the problem of fluorescence quenching due to SDS and Joule heating, it is not suitable for the analysis of large-volume protein samples, mainly because of serious protein adsorption effects. The adsorption of proteins and matrixes on the capillary wall usually takes place through Coulombic interactions, hydrogen bonding, and/or hydrophobic patches and leads to losses in resolution and reproducibility. To overcome these problems, CE has been performed using polymers, such as PEO, hydroxycellulose derivatives, and LPA, that possess self-coating and sieving capabilities. ${ }^{24,31}$

The primary goal of this study was to develop a technique that allows the on-line concentration and analysis of microheterogeneous proteins to be conducted by CE-LIF. In a previous study, ${ }^{27}$ we used a Nd:YAG laser for protein analysis; the sensitivity for most of the tested proteins was at the $\mathrm{nM}$ level. Unfortunately, this laser is expensive (ca. US\$ 50 000), requires special maintenance, and has a high plasma background. Herein, we tested a new and relatively low-cost (ca. US\$ 12 000) diode-pumped solid-state nanolaser for its suitability toward protein analysis. By taking advantage of the segmental filling technique and minimizing protein adsorption by adding SDS and/or PEO to the samples, we have managed to separate large volumes of protein samples (ca. $1.0 \mu \mathrm{L}, 0.1$ $\mu \mathrm{M})$ by using CE-LIF. We have carefully investigated the effects that the $\mathrm{pH}$, the presence of the SDS plug, and the concentrations of SDS and PEO have on the stacking efficiency, resolution, and reproducibility during the analyses of proteins by CELIF. Our results suggest that this proposed method has great potential for the analysis of trace proteins in biological samples and for proteomics applications.

\section{Experimental Section}

Apparatus. The basic design of the separation system has been described previously. ${ }^{27}$ Briefly, a high-voltage power supply (Gamma High Voltage Research Inc., Ormond Beach, FL) was used to drive electrophoresis. The entire detection system was enclosed in a black box having a high-voltage interlock. The high voltage end of the separation system was housed in a Plexiglass box for safety. A diode-pumped solidstate nanolaser (JDS Uniphase, Manteca, CA) having a 5-mW output at $266 \mathrm{~nm}$ was used to induce intrinsic fluorescence. To minimize interference from the laser plasma, a UG1 filter (Barrington, Edmund, NJ) was placed at the exit of the laser light. UG1 filter is an interference filter with the transmitted wavelength centered at $360 \mathrm{~nm}$ and the effective bandwidths of $60 \mathrm{~nm}$. The intrinsic fluorescence $(310-350 \mathrm{~nm})$ of the proteins was collected using a $10 \times$ objective (numerical aperture $=0.25$ ) before reaching the photomultiplier tube (R928 from Hamamatsu, Shizuoka-Ken, Japan). The amplified current was transferred directly through a $10-\mathrm{k} \Omega$ resistor to a 24 -bit A/D interface at $5 \mathrm{~Hz}$ (Borwin, JMBS Developments, Le Fontanil, France) and the data were stored in a personal computer. When compared with the results obtained when using a $\mathrm{Nd}$ : YAG laser, the nanolaser provides a ca. 5-10-times lower sensitivity toward the proteins tested in this study, mainly because of its relatively poor stability. A laboratory-made CE equipped with a UV-Vis absorption detector (Ecom Spol. S.R.O., Czech Republic) was used to analyze standard protein samples under discontinuous conditions. Fused silica capillaries (Polymicro Technologies, Phoenix, AZ) having $75-\mu \mathrm{m}$ i.d. and $365-\mu \mathrm{m}$ o.d. were used in the whole experiments for protein separations.

Chemicals. SDS, proteins, and all chemicals for preparing buffers were obtained from Sigma (St Louis, MO). Table 1 lists some chemical and physical properties of the model proteins. PEO polymers $\left(M_{\mathrm{w}} 300000\right.$ and 4000000$)$ were obtained from 
Aldrich (Milwaukee, WI). TB solutions (2.0 and 0.2 M) prepared from tris(hydroxymethyl)aminomethane (Tris) were adjusted with boric acid to $\mathrm{pH} 10.5$ and 9.0, respectively. In this manuscript, the molarity of the TB buffer refers to that of its Tris component. Solutions of trypsin inhibitor (TI), $\beta$-casein $(\beta$-CAS), ovalbumin (OVA), bovine serum albumin (BSA), human serum albumin (HSA), $\alpha$-lactalbumin ( $\alpha$-LAC), and carbonic anhydrase (CA) were prepared in water and stored at $4{ }^{\circ} \mathrm{C}$. Prior to use, they were diluted to $0.1 \mu \mathrm{M}$ or $1.0 \mu \mathrm{M}$ in $1.0-100.0 \mathrm{mM}$ TB solutions ( $\mathrm{pH} 4.0-10.0$ ) containing $0-0.025 \%$ SDS or $0-0.01 \%$ PEO $\left(M_{\mathrm{w}} 300000\right)$.

Polymer Solutions. $1.7 \%$ PEO ( $\left.M_{\mathrm{w}} 4000000\right)$ solution that was used as sieving matrixes was prepared in $0.2 \mathrm{M}$ TB solution (pH 9.0), while $0-0.01 \%$ PEO $\left(M_{\mathrm{w}} 300000\right)$ solutions were prepared in 1.0-100.0 mM TB ( $\mathrm{pH} 10.0)$. Increasing amounts of PEO were gradually added to the TB solutions in a water bath at $85-90^{\circ} \mathrm{C}$ under constant stirring to produce a homogeneous suspension. After the final addition of PEO, the solutions were stirred for another hour. The PEO solutions were stored in a refrigerator at $4{ }^{\circ} \mathrm{C}$ after being degassed with a vacuum system in an ultrasonic tank. The polymer solutions were usable for 4 days.

Treatment of Capillaries and Separation. Capillaries were treated with $0.5 \mathrm{M} \mathrm{NaOH}$ overnight prior to use. The capillaries used for the experiments in CE-LIF and in CE with UV-Vis detection are 40 and $48 \mathrm{~cm}$, respectively. The detection points are $10 \mathrm{~cm}$ from the capillary outlets in both cases. Between runs, the capillaries were washed with $0.5 \mathrm{M} \mathrm{NaOH}$ at $1.0 \mathrm{kV}$ for $10 \mathrm{~min}$ to remove the polymer solutions and refresh the capillary wall. This method has proven to be useful for achieving reproducible EOF; relative standard deviation (RSD) values were below $3.0 \%$ over 10 consecutive runs. ${ }^{39-41}$ The bulk EOF mobility was determined by the time at which the baseline shifts as a result of detection of PEO (neutral molecules). This method was also validated by injecting $1.0 \mu \mathrm{M}$ naphthalene solution in the absence of SDS. The SDS solution and model protein samples were both prepared in $10.0 \mathrm{mM}$ TB solution ( $\mathrm{pH}$ 10.0). Prior to injection of a protein sample by raising the capillary inlet $30-\mathrm{cm}$ height $(30-\mathrm{cm}$ height pressure difference between the capillary inlet and outlet) for a period of time up to $3 \mathrm{~min}$, a plug of $0.2 \%$ or $1.0 \%$ SDS solution, which was prepared in $10.0 \mathrm{mM} \mathrm{TB}$ solution at $\mathrm{pH} 10.0$, was injected hydrodynamically by raising the capillary inlet $30-\mathrm{cm}$ height for $20 \mathrm{~s}(2.5 \mathrm{~cm})$ into a capillary filled with $2.0 \mathrm{M} \mathrm{TB}(\mathrm{pH} 10.5)$. The ends of the capillary were then immersed in the cathodic and anodic vials containing 1.7\% PEO solution ( $\mathrm{pH} 9.0$ ). Once a high voltage $(12.5 \mathrm{kV})$ was applied, the PEO solution in the anodic reservoir entered the capillary under EOF.

Urine Analysis. Urine samples were collected from a healthy female and were subjected to separation without any pretreatment. The urine sample was diluted by a factor of $10(0.1 \times)$ in $10.0 \mathrm{mM}$ TB ( $\mathrm{pH} 10.0)$ containing $0.01 \%$ PEO. For the determination of the HSA concentration, standard HSA solutions (1.0-100 $\mu \mathrm{M}, 1.0 \mu \mathrm{L})$ were spiked into aliquots $(99.0 \mu \mathrm{L})$ of urine samples; the final concentrations ranged from 0.01 to $1.0 \mu \mathrm{M}$. The samples were injected separately into a capillary filled with 2.0 M TB solution ( $\mathrm{pH} \mathrm{10.5)} \mathrm{at} \mathrm{30-cm} \mathrm{height} \mathrm{for} 2 \mathrm{~min}$ and were separated at $12.5 \mathrm{kV}$.

Analysis of Human Red Blood Cells (RBCs). Fresh blood $(10.0 \mu \mathrm{L})$ from a healthy adult male was diluted to $1.0 \mathrm{~mL}$ using phosphate-buffered saline (PBS), which consisted of $37.0 \mathrm{mM}$ phosphate $(\mathrm{pH} 7.4)$ and $38.0 \mathrm{mM}$ sodium chloride, followed by centrifugation and removal of the supernatant to leave only
Table 2. Comparison of Migration Times, Peak Heights, and Resolutions for Proteins Prepared in Different TB Buffers $(\mathrm{pH}$ 10.0)

\begin{tabular}{|c|c|c|c|c|c|}
\hline \multirow[b]{2}{*}{$\mathrm{TB}(\mathrm{mM})^{a}$} & \multicolumn{2}{|c|}{$\begin{array}{c}\text { migration time } \\
(\min )(\mathrm{RSD}, n=3)\end{array}$} & \multicolumn{2}{|c|}{$\begin{array}{l}\text { peak height } \\
(\mathrm{mV})\end{array}$} & \multirow{2}{*}{$\frac{\text { resolution }}{\alpha-\mathrm{LAC} / \mathrm{BSA}}$} \\
\hline & $\alpha-\mathrm{LAC}^{b}$ & $\mathrm{BSA}^{c}$ & $\alpha-\mathrm{LAC}^{b}$ & $\mathrm{BSA}^{c}$ & \\
\hline 100.0 & $16.71\left(3.72^{\circ}\right.$ & $16.92\left(3.64^{\circ}\right.$ & 11. & & \\
\hline 50.0 & $19.86(1.74 \%)$ & $20.15(1.47 \%)$ & 19.4 & 10.9 & 3.3 \\
\hline 10.0 & 23.60 (1.05\%) & $23.89(1.30$ & 20.6 & 14. & 4.2 \\
\hline 1.0 & $28.73(2.81 \%)$ & $29.08(2.70 \%)$ & 18.7 & 14.0 & 5.7 \\
\hline
\end{tabular}

${ }^{a} 0.01 \%$ SDS as additive. ${ }^{b}$ The major peak marked as 2 in Figure $1 .{ }^{c}$ The major peak marked as 3 in Figure 1.

the intact cells without the plasma. The cell pellet was then diluted with PBS solution $(1.0 \mathrm{~mL})$. A sample $(10.0 \mu \mathrm{L})$ of the washed RBC was lysed by adding $10.0 \mathrm{mM}$ TB (pH 10.0; 10.0 $\mathrm{mL}$ ) containing $0.01 \% \mathrm{PEO}$, which gave a final dilution of ca. $10^{5} \times$. We note that the protein contents per $\mu \mathrm{L}$ of the lysed $\mathrm{RBC}$ sample were approximately the same as those in $50 \mathrm{RBCs}$ on the basis of $5 \times 10^{6}$ cells per $\mu \mathrm{L}$ of blood.

\section{Results and Discussion}

Generation of Reproducible EOF. When injecting a large volume of a protein sample (ca. $1.0 \mu \mathrm{L}, 0.1 \mu \mathrm{M}$ ), the roles of the ionic strength, $\mathrm{pH}$, and additives are extremely important in determining the resolution, speed, sensitivity (quantum yield and stacking efficiency), and reproducibility. ${ }^{22}$ The $\mathrm{pH}$ of the buffer is an important parameter that affects the resolution and sensitivity of the analysis of proteins by CE-LIF. Because fluorescence quenching and adsorption of PEO and proteins cause losses in sensitivity, resolution, and reproducibility at low $\mathrm{pH}$, protein analysis by CE-LIF is conducted most favorably at high $\mathrm{pH}$. Most proteins' intrinsic fluorescence intensities reach their maxima at values of $\mathrm{pH}$ of ca. 10.2. In a previous paper, we suggested that PEO adsorption is diminished when high concentrations of TB solutions were used to fill the capillary and to prepare the PEO solutions. ${ }^{22,40}$ We also suggested that, to achieve a reproducible EOF, it is essential to treat the capillary with $0.5 \mathrm{M} \mathrm{NaOH}$ after each run. Thus, we conducted the protein analyses in this study by using a capillary filled with $2.0 \mathrm{M}$ TB solution ( $\mathrm{pH}$ 10.5) and a $1.7 \%$ PEO solution that was prepared in $0.2 \mathrm{M} \mathrm{TB}$ (pH 9.0). When injecting a $1.0-\mu \mathrm{L}$ protein sample $(0.1 \mu \mathrm{M})$ that was prepared in $10 \mathrm{mM}$ TB solution $(\mathrm{pH}$ 10.0) containing $0.01 \%$ SDS, the bulk EOF mobility was $1.6 \times$ $10^{-4} \mathrm{~m}^{2} \mathrm{~V}^{-1} \mathrm{~s}^{-1}$, with a RSD value of $2.5 \%$ over 10 consecutive runs.

Optimization of Stacking Efficiency. Adsorptions of proteins and PEO are serious problems at low ionic strengths and they lead to long separation times, poor resolution, and irreproducibility. On the other hand, the loss of stacking efficiency and fluorescence quenching caused by salt must be considered when protein samples are prepared in high-conductivity media. To elucidate the impact of the ionic strength, we conducted the analyses of ca. $1.0 \mu \mathrm{L}$ of $0.1 \mu \mathrm{M}$ protein samples (3-min injection) that had been prepared in 1.0-100.0 mM TB solutions ( $\mathrm{pH} 10.0$ ) containing $0.01 \%$ SDS. We note that the addition of $0.01 \%$ SDS to the protein samples was essential for high efficiency (see discussion below). Upon increasing the TB concentration, we found that the separation time decreased and the stacking efficiency also decreased (smaller peak heights), as listed in Table 2. Although the separation was faster when using the $100.0 \mathrm{mM}$ TB solution, this benefit was offset 
by a loss of stacking efficiency (smaller peaks) and resolution. In terms of the optimal resolution, speed, and sensitivity, we suggest that the proteins have to be prepared in 10.0-50.0 mM TB when conducting on-line concentration.

SDS, which had a critical micelle concentration (CMC) of $0.24 \%$ in water, not only affects the physical and chemical properties of protein complexes but also minimizes protein aggregation and protein adsorption on the capillary wall. ${ }^{27,42-44}$ Thus, it is commonly added to background electrolytes to improve the efficiency and reproducibility of protein analyses performed using CE. The high fluorescence background caused by the impurity and fluorescence quenching must be considered, however, when adding SDS to background electrolytes. ${ }^{27}$ The problems are even more serious when injecting large volumes of proteins prepared in TB solutions containing SDS as an additive. To prevent these problems, we suggested that proteins are prepared in TB solutions containing low amounts of SDS ( $\ll$ CMC). When injecting a large-volume protein sample, the proteins that migrate against the EOF slow and become stacked, as a result of sieving and increases in viscosity, when they enter the PEO zone. Electropherograms A-F in Figure 1 indicate the dramatic effect that SDS has on the separations of CA, $\alpha$-LAC, and BSA samples prepared in 50.0 mM TB solutions ( $\mathrm{pH} 10.0$ ) containing $0-0.025 \%$ SDS. The peak denoted by the letter "s" is a system peak, corresponding to impurities from SDS and PEO; it overlapped partially with the peak for CA (peak 1). Slight increases in the time at the baseline shift reveal that the EOF decreased upon increasing the SDS concentration (ionic strength), as a result of decreases in the zeta potential. The changes in the peak profile and migration times for the three proteins further indicate the formation of different SDS-protein complexes, which is consistent with the SDS concentration dependence of the binding behaviors of the protein complexes; the greater the hydrophobicity of the proteins, the stronger are their interactions with SDS. ${ }^{44}$ We note that the electrophoretic mobility of CA changed slightly, which indicates that its interaction with SDS is the weakest among the three proteins. From a comparison of the electropherograms, adding $0.01 \%$ SDS to the protein sample is the most suitable condition because of the greater separation efficiencies provided to peaks 2 and 3 (the major one); their plate numbers were $3.4 \times 10^{6}$ and $2.3 \times 10^{5}$, respectively. Thus, we chose to use $0.01 \%$ SDS for the remainder of this study.

Next, we investigated the role that the sample $\mathrm{pH}$ has on the resolution and sensitivity by conducting the analyses of proteins prepared in $10.0 \mathrm{mM}$ TB solutions at $\mathrm{pH} 4.0,6.0$, and 8.0. We used $10.0 \mathrm{mM} \mathrm{TB}$, rather than $50.0 \mathrm{mM} \mathrm{TB}$, to minimize Joule heating. In comparison with Figure 1E, electropherogram A in Figure 2 exhibits poorer resolution at $\mathrm{pH} 4.0$, as we had expected. Protein adsorption is a serious problem at such a low value of $\mathrm{pH}$, even in the presence of SDS. Electropherograms $\mathrm{B}$ and $\mathrm{C}$ indicate that the relative distances between peaks 2 and 3 are different at the various values of $\mathrm{pH}$. The electropherograms also display that the efficiencies for $\alpha$-LAC and BSA obtained at $\mathrm{pH} 6.0$ and 8.0 are slightly better than those at $\mathrm{pH}$ 10.0. In the absence of SDS, we expected protein adsorption and $\mathrm{pH}$ quenching to occur. Thus, our results suggest that protein adsorption is suppressed as a result of the formation of SDS-protein complexes. In contrast, the fluorescence intensity of CA (weak interactions with SDS) decreases and band broadening becomes serious upon decreasing the $\mathrm{pH}$ as a result of CA's weak interactions with SDS; this finding again confirms the important role that SDS plays in minimizing

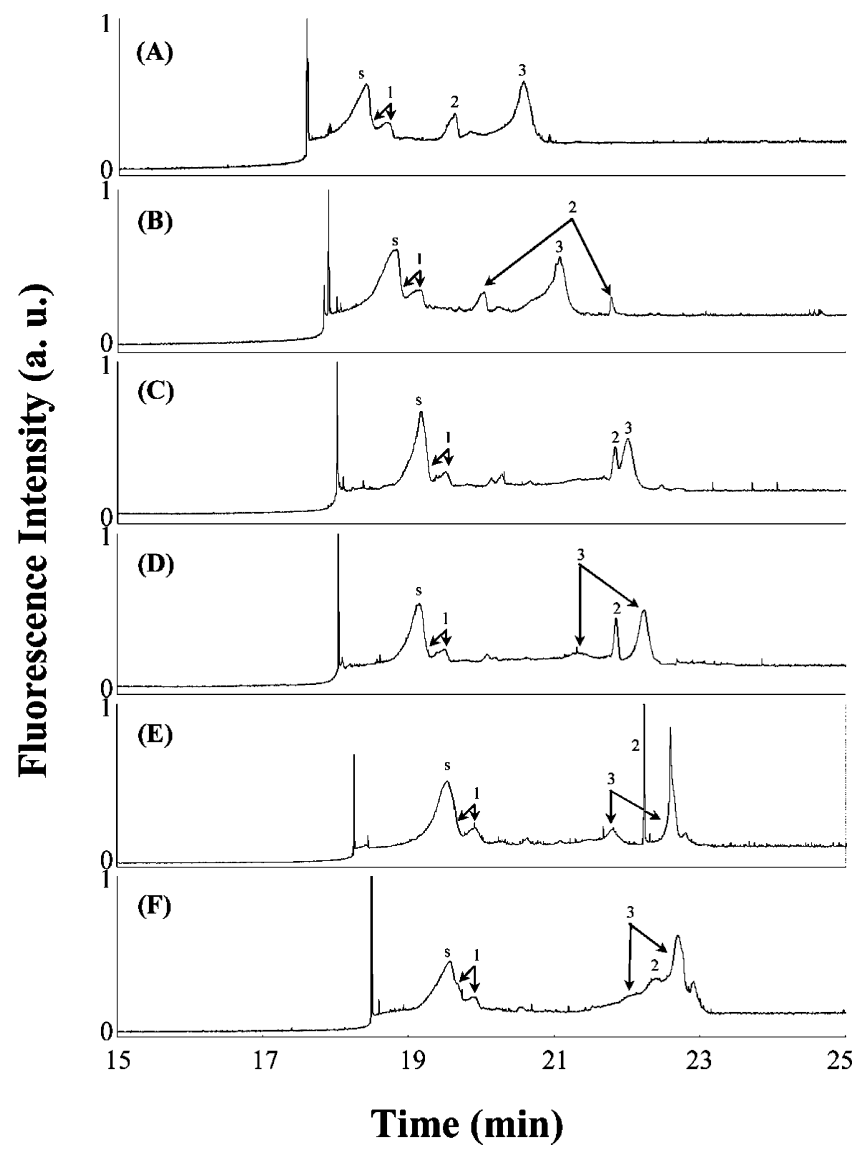

Figure 1. Effect that SDS addition in samples has on separating $1.0-\mu \mathrm{L}$ protein samples by CE with LIF detection at $12.5 \mathrm{kV}$ using PEO. A $40-\mathrm{cm}$ capillary (75- $\mu \mathrm{m}$ i.d., $365-\mu \mathrm{m}$ o.d., effective length: $30 \mathrm{~cm}$ ) was filled with $2.0 \mathrm{M}$ TB buffer $(\mathrm{pH} 10.5)$. Buffer vials contained $1.7 \%$ PEO, which was prepared in $0.2 \mathrm{M}$ TB solution $(\mathrm{pH} 9.0)$. (A)-(F): SDS concentrations in protein samples were $0,0.0005,0.0025,0.005,0.01$, and $0.025 \%$, respectively. Protein concentrations were $0.1 \mu \mathrm{M}$ and they were prepared in $50.0 \mathrm{mM}$ TB buffer ( $\mathrm{pH}$ 10.0). Samples were hydrodynamically injected by raising the capillary inlet $30-\mathrm{cm}$ height for $3 \mathrm{~min}$. The separations were conducted at $12.5 \mathrm{kV}(312.5 \mathrm{~V} / \mathrm{cm})$ at $26^{\circ} \mathrm{C}$. The excitation wavelength is $266 \mathrm{~nm}$ and the fluorescence over the wavelength range of $310-350 \mathrm{~nm}$ is collected. Peak identities: s, system peak; 1, CA; 2, $\alpha$-LAC; 3, BSA. The fluorescence intensities are plotted in arbitrary units (a. u.).

protein adsorption. On the basis of these results, we infer that it is possible to conduct protein analyses at low $\mathrm{pH}$ in the presence of SDS if the proteins have strong interactions with SDS, but it is favorable at high $\mathrm{pH}$ if the protein-SDS complexes are unstable.

Improved Separation Efficiency. In our previous study, ${ }^{27}$ we demonstrated an improvement in the efficiency of the microheterogeneity of separating proteins $(\mathrm{nL})$ by controlling the SDS concentration and its plug length. Herein, we further tested the possibility of applying an SDS plug for improving efficiency of the separations of $1.0-\mu \mathrm{L}$ protein samples containing $\mathrm{CA}, \mathrm{TI}$, $\alpha$-LAC, BSA, $\beta$-CAS, and OVA $(0.1 \mu \mathrm{M})$ by CE-LIF. From a series of experiments $(0.1-1.0 \%$ SDS; injection time: $10-60 \mathrm{~s})$, we have found that injecting $0.2 \%$ SDS (10.0 $\mathrm{mM} \mathrm{TB}$ at $\mathrm{pH} 10.0)$ for $20 \mathrm{~s}$ prior to sample injection provides the best separation and stacking performance (data not shown). Electropherograms A (without SDS plug) and B depicted in Figure 3 exhibit different peak patterns that demonstrate the impact of the SDS 

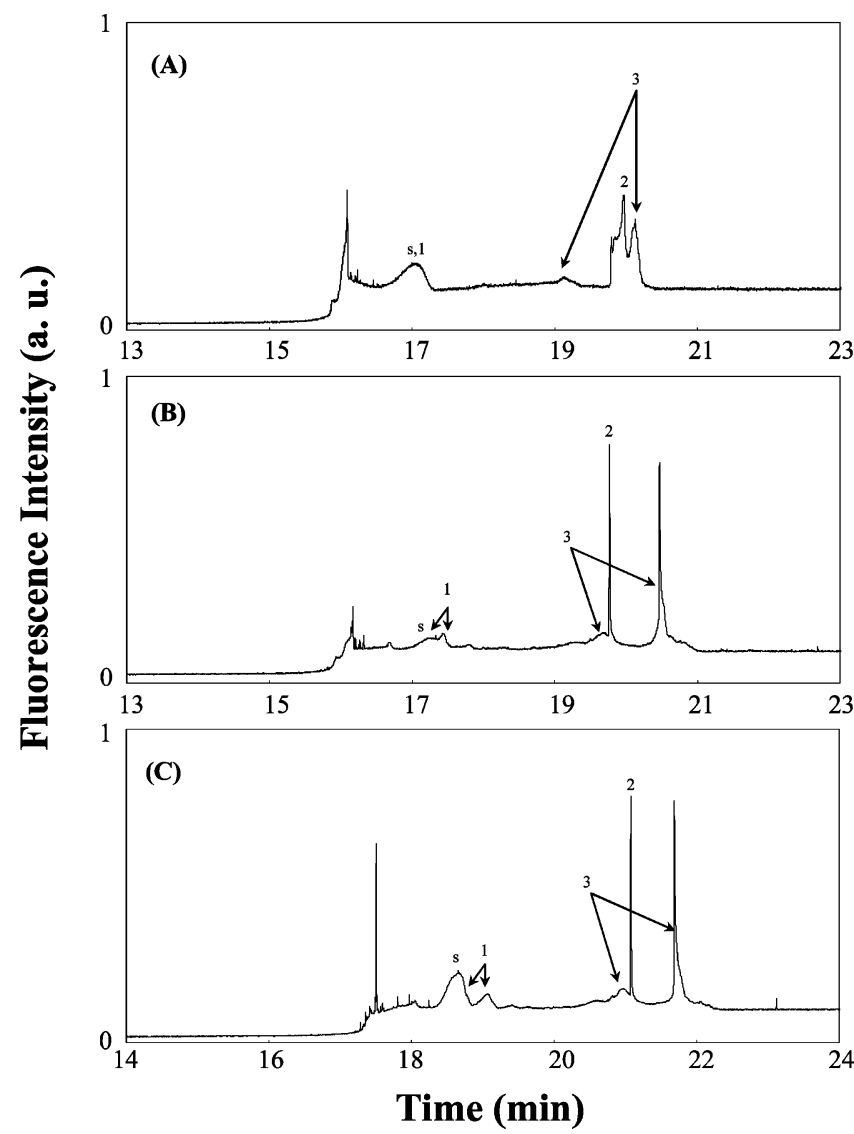

Figure 2. Effect of sample $\mathrm{pH}$ on the separation of 1.0- $\mu \mathrm{L}$ protein samples $(0.1 \mu \mathrm{M})$ by CE with LIF detection at $12.5 \mathrm{kV}$ using PEO. Proteins were prepared in $10.0 \mathrm{mM}$ TB solutions $(\mathrm{pH} 10.0)$ containing $0.01 \%$ SDS. The values of $\mathrm{pH}$ of the samples in (A), (B), and (C) were 4.0,6.0, and 8.0, respectively. Peak identities: s, system peak; $1, C A ; 2, \alpha$-LAC; 3, BSA. Other conditions are the same as those provided in Figure 1.

plug. In the presence of an SDS plug, we resolved a greater number of peaks for CA and OVA. It is important to highlight that the limit of detection (LOD) at a signal-to-noise ratio (S/ $\mathrm{N}$ ) of 3 for $\alpha$-LAC was $0.48 \mathrm{nM}$, which is an 84 -fold improvement in sensitivity when compared to that obtained using a conventional method (30-cm height for $10 \mathrm{~s}$ ). The reproducibility values of the migration times and the peak heights for CA; TI; $\alpha$-LAC; BSA; $\beta$-CAS; and OVA were in the ranges of 3.5$4.5 \%$ and $0.5-10.0 \%$, respectively. The reproducibility values for the proteins obtained without applying an SDS plug were $0.96-3.5 \%$ (migration times) and $5.5-20.0 \%$ (peak height). Improved reproducibility in the peak height is mainly due to a better resolution and minimum protein adsorption in the presence of the SDS plug. While a nonuniform electric field inside the capillary is a main reason for the loss in reproducibility when applying the SDS plug. We note that the analysis of the microheterogeneity of a large-volume protein sample failed when the sample was prepared in $10.0 \mathrm{mM}$ TB solution ( $\mathrm{pH}$ 10.0) that did not contain SDS. The separations of $1.0-\mu \mathrm{L}$ protein samples $(0.1 \mu \mathrm{M})$ by CE-LIF using PEO solutions and protein samples that both contained the same concentrations of SDS over the range $0.01-0.2 \%$ (other conditions are similar to those described in Figure 1) were also unsuccessful. The separation speed increased, while the resolution decreased, upon increasing the SDS concentration (not shown). We could identify only two peaks-corresponding to BSA and OVA,

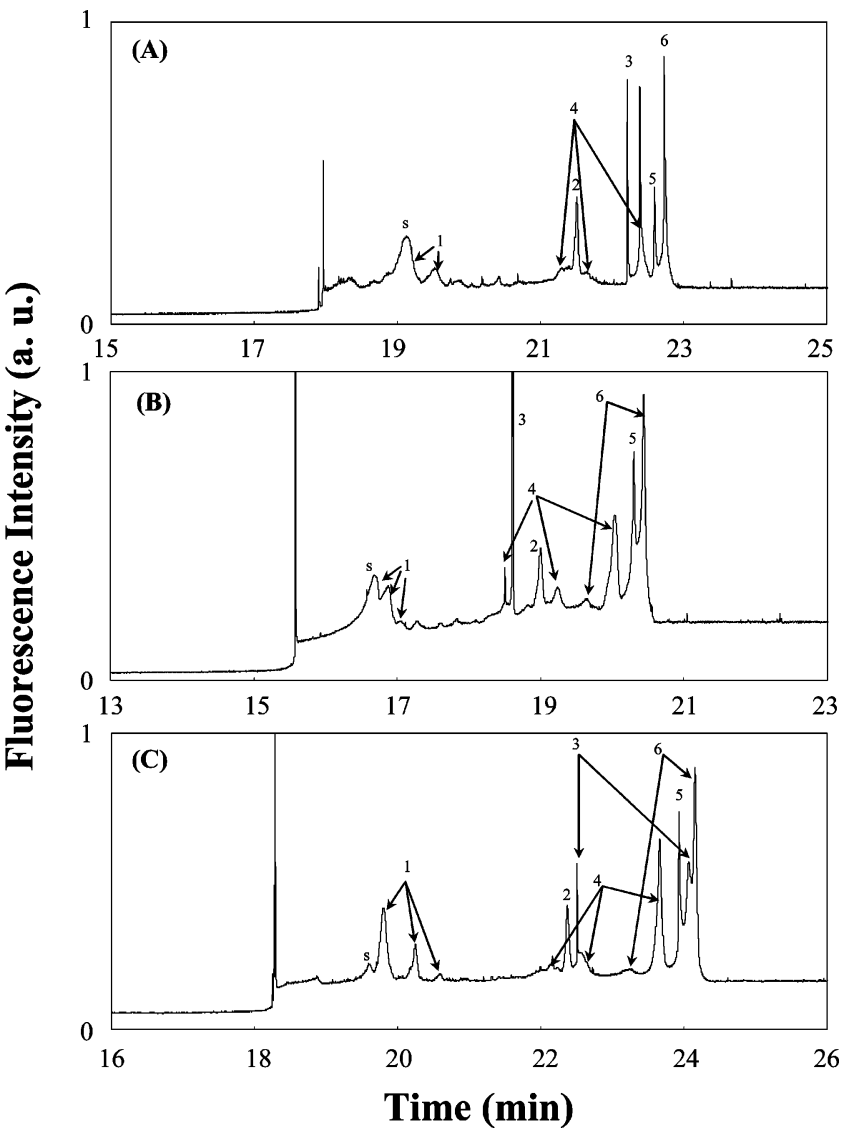

Figure 3. Separations of $1.0-\mu \mathrm{L}$ protein samples by CE with LIF detection in the $(A)$ absence and $(B, C)$ presence of an SDS plug $(0.2 \%$, ca. $2.5 \mathrm{~cm})$ at $12.5 \mathrm{kV}$ using PEO. The samples in $(A)$ and (B) were prepared in $10.0 \mathrm{mM}$ TB solutions $(\mathrm{pH} 10.0)$ containing $0.01 \%$ SDS, while those in $(C)$ were prepared in $10.0 \mathrm{mM}$ TB solution ( $\mathrm{pH} 10.0$ ) containing $0.01 \%$ PEO. Protein concentrations were $0.1 \mu \mathrm{M}$. Peak identities: s, system peak; $1, \mathrm{CA} ; 2, \mathrm{Tl} ; 3$, $\alpha$-LAC; 4 , BSA; $5, \beta$-CAS; 6 , OVA. Other conditions are the same as those provided in Figure 1.

between 23 and $24 \mathrm{~min}$-in the presence of $0.01 \%$ SDS, while only one broad peak appeared (at ca. $7.5 \mathrm{~min}$ ) in the presence of $0.2 \%$ SDS. Under the same separation conditions, our analyses of the sample containing the six proteins $(1.0 \mu \mathrm{M})$ were also failed when using CE in conjunction with UV-Vis absorption detection. These results suggest that SDS caused poor stacking efficiency, poor resolution, and fluorescence quenching under isocratic conditions. On the basis of these results, we suggested that the short SDS plug plays two major roles in affecting the results: it prevents PEO adsorption on the capillary wall and increases the stacking efficiency, similar to the sweeping mechanism proposed by Terabe et al. ${ }^{45}$ Upon increasing the SDS concentration, more SDS molecules bound to the proteins, which led to increases in the migration mobility of SDS-protein complexes toward the anodic end. As a result, stacking of the SDS-protein complexes might take place before they entered the PEO zone.

To test the notion that the stacking of proteins is due partially to the sweeping mechanism, we prepared a protein sample in $10.0 \mathrm{mM}$ TB solution ( $\mathrm{pH}$ 10.0) without adding SDS. To prevent protein adsorption and retain the good stacking due to sieving and increases in viscosity, we prepared the protein samples in a TB solution containing $0.01 \%$ PEO. In the absence of SDS, proteins migrate slowly against the EOF. Once they interact 
Table 3. Impacts of Sample Additives on the Values of Linear Regression (LR), Linear Regression Coefficient $\left(R^{2}\right)$, LOD, Sensitivity Enhancement (SE), and Efficiency $(N)$ for Various Proteins

\begin{tabular}{|c|c|c|c|c|c|c|c|c|c|c|}
\hline \multirow[b]{2}{*}{$\operatorname{protein}^{c}$} & \multicolumn{5}{|c|}{$0.01 \% \operatorname{SDS}^{a}$} & \multicolumn{5}{|c|}{$0.01 \% \mathrm{PEO}^{b}$} \\
\hline & $\mathrm{LR}^{d}$ & $R^{2}$ & LOD (nM) & SE & $N\left(\times 10^{5}\right)$ & $\mathrm{LR}^{d}$ & $R^{2}$ & LOD (nM) & SE & $N\left(\times 10^{5}\right)$ \\
\hline $\mathrm{CA}$ & N. D. ${ }^{e}$ & N. D. & N. D. & N. D. & N. D. & $y=4.9 x-124.6$ & 0.994 & 8.2 & 28 & 5.0 \\
\hline$\alpha$-LAC & $y=75.2 x-1510$ & 0.927 & 0.48 & 84 & 430 & N. D. & N. D. & N. D. & N. D. & N. D. \\
\hline $\mathrm{TI}$ & $y=5.9 x+303.0$ & 0.956 & 1.4 & 90 & 8.6 & $y=4.6 x+362.8$ & 0.999 & 2.0 & 62 & 10.0 \\
\hline BSA & $y=12.7 x+316.0$ & 0.947 & 1.1 & 49 & 4.5 & $y=10.8 x+746.8$ & 0.997 & 0.71 & 76 & 8.6 \\
\hline OVA & $y=33.1 x-526.3$ & 0.990 & 0.61 & 61 & 7.5 & $y=8.5 x+1290.7$ & 0.980 & 0.91 & 32 & 10.0 \\
\hline
\end{tabular}

${ }^{a}$ From Figure 3B. ${ }^{b}$ From Figure 3C. ${ }^{c}$ The major peak. ${ }^{d} y$ is the peak height (a. u.) and $x$ is the injection time (s) at $30-\mathrm{cm}$ height for $60-180 \mathrm{~s} .{ }^{e}$ Not detected.

with SDS from the SDS plug, they speed up, which leads to greater stacking efficiency. Figure 3C indicates the fact that the microheterogeneities of the proteins are different from those displayed in Figure 3B. We note that the three peaks for CA are resolved in the baseline (Figure 3C), mainly because the impurity from PEO interferes less when compared to that from SDS. Although the resolving power improved, this approach still does not provide enough resolving power for complete separation of the CA microheterogeneities. It has suggested that CA consists of various isoenzymes ranging from $\mathrm{pH} 5.1$ to $5.9 .^{33}$ The reproducibility values of the migration times and the peak heights for the peaks corresponding to CA; TI; $\alpha$-LAC; BSA; $\beta$-CAS; and OVA were $<2.0-3.5 \%$ and $0.2-4.5 \%$, respectively. Both electropherograms display three, three, and two resolved peaks for CA, BSA, and OVA, respectively; in contrast, there are one and two peaks corresponding to $\alpha$-LAC in the case where we used SDS and PEO, respectively. The three peaks for BSA are likely corresponding to BSA monomers with a mixed disulfide bond (nonmercaptoalbumin) and with a free sulfhydryl group (mercaptoalbumin), as well as a BSA monomer after posttranslational modifications, such as deamidation of Asn or Gln, acetylation of basic side chains, or binding of certain acid compounds. ${ }^{38}$ OVA is a glycoprotein of avian egg white with at least nine different oligosaccharide chains that have been identified. The result suggests that our approach does not provide a resolving power for the separation of the microheterogeneity of OVA, which may be achieved by adding suitable additives such as hydroxylamine to the running buffer. ${ }^{37}$ Two peaks were detected for $\alpha$-LAC, suggesting that the sample contained $\alpha-(\mathrm{p} I 5.15)$ and $\beta$ - (pI 5.3) forms of LAC. ${ }^{35}$ Although we could not clearly observe the impact of the sweeping mechanism on our method because of a significant difference in the appearances of the peak patterns, comparable sensitivity (stacking efficiency) suggests that the main stacking mechanism is due to the presence of the PEO zone as a result of increases in viscosity and sieving. Table 3 summarizes the differential effects that SDS and PEO in the protein samples have on these protein analyses. The plate numbers for the proteins are all $>10^{5}$ (e.g., for TI it is $>1.0 \times 10^{6}$ ), which indicates a high stacking efficiency and minimum protein adsorption. The LODs $(S / N=3)$ for the proteins are all on the $n M$ to sub-nM level. We note that the sensitivity can be improved further when a more stable (continuous) UV laser, such as argon ion laser, is employed.

Comparison of LIF and UV-Vis Detection. Using the same stacking and separation conditions, we analyzed a $1.0-\mu \mathrm{L}$ protein sample containing the six proteins at concentrations of $1.0 \mu \mathrm{M}$ by CE in conjunction with a UV-Vis detector. We point out that high concentrations of proteins are required because of relatively poor sensitivity (ca. 10 times worse than that obtained by LIF for CA). The peaks corresponding to CA

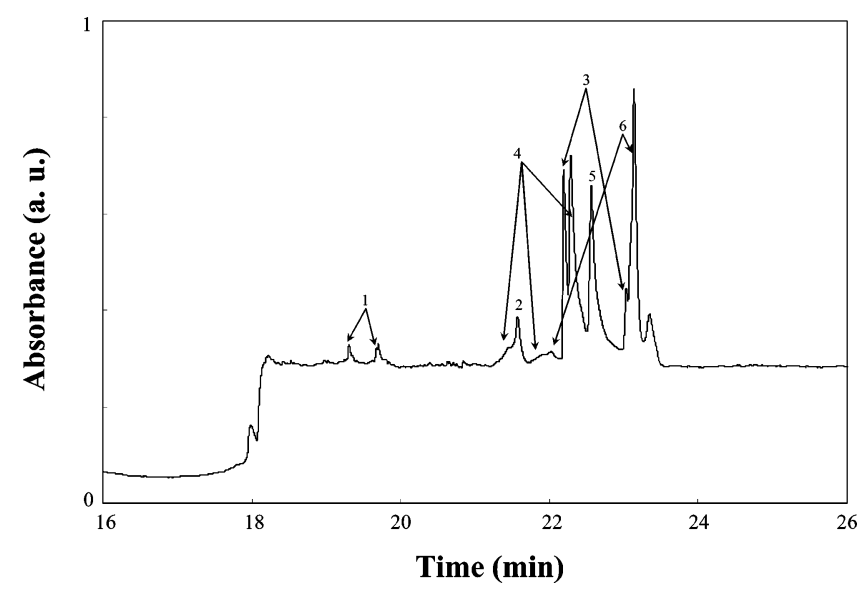

Figure 4. Separation of a $1.0-\mu \mathrm{L}$ protein sample by CE with UVVis detection in the presence of a SDS plug $(1 \%$, ca. $2.5 \mathrm{~cm})$ at $12.5 \mathrm{kV}$ using PEO. A 48-cm capillary (effective length: $38 \mathrm{~cm}$ ) was filled with $2.0 \mathrm{M}$ TB buffer $(\mathrm{pH} 10.5) .1 .0 \mu \mathrm{M}$ proteins were prepared in $10.0 \mathrm{mM}$ TB $(\mathrm{pH} 10.0)$ containing $0.01 \%$ PEO. The detection wavelength was set at $214 \mathrm{~nm}$. Peak identities: 1, CA; 2 , TI; $3, \alpha$-LAC; 4 , BSA; $5, \beta$-CAS; 6 , OVA. The absorbance is plotted in absorbance unit (a. u.). Other conditions are the same as those described in Figure $3 \mathrm{C}$.

and the small peaks corresponding to the microheterogeneities of BSA, $\alpha$-LAC, and OVA could be detected only when their concentrations were $1.0 \mu \mathrm{M}$. To achieve better resolution, we injected a $1.0 \%$ SDS plug prior to sample injection. The electropherogram in Figure 4 displays the microheterogeneity of the proteins. The slight difference between this electropherogram and those depicted in Figure 3B,C is due mainly to the different protein/SDS concentration ratios in the three samples. When compared with Figure 3B,C, we observe in Figure 4 a large baseline shift that is due mainly to PEO absorption after it entered the detection area. The migration times for the proteins are slightly different, mainly because of differential effective lengths and ambient temperatures (15 vs $26{ }^{\circ} \mathrm{C}$ ). The viscosity of PEO decreased upon increasing the temperature; this phenomenon causes a greater EOF.

Analysis of Large-Volume Biological Samples. Urine contains low concentrations of proteins such as HSA in the presence of a complicated matrix; these properties make it a suitable candidate for testing the applicability of our proposed methods. Figure 5 indicates that there are many peaks detected in the urine sample (2-min injection; ca. $0.67 \mu \mathrm{L})$. The first big peak at ca. $8.4 \mathrm{~min}$ corresponds to tryptophan $(40 \mathrm{mg} / \mathrm{L}$ in healthy urine); it can be detected without applying the sample stacking technique (10-s injection). Because only the analytes that have intrinsic fluorescence can be detected using this method, the other peaks could be those of species such as 


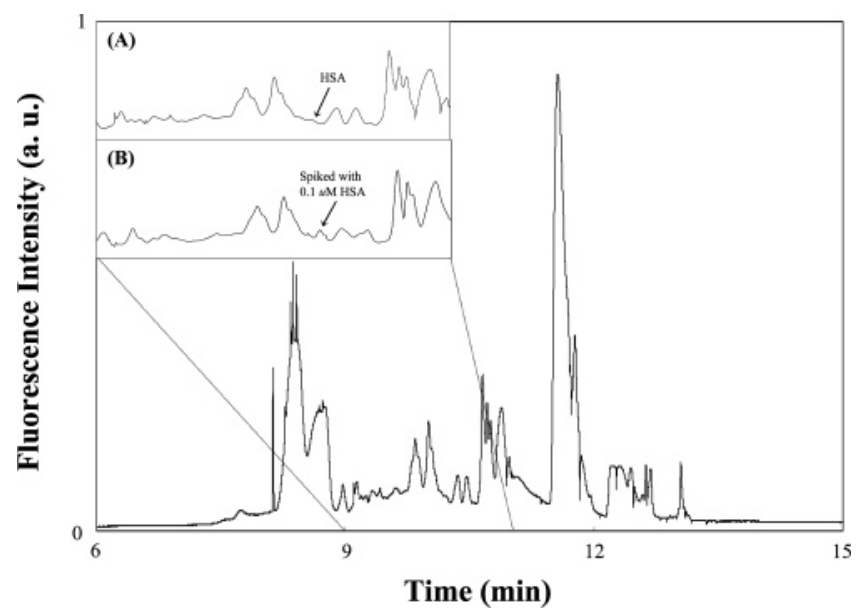

Figure 5. On-line concentration and separation of a urine sample by CE with LIF detection. Urine samples were diluted by a factor of 10 in $10.0 \mathrm{mM}$ TB solution $(\mathrm{pH} 10.0)$ containing $0.01 \%$ PEO. Samples (A) without and (B) with spiking of $0.1 \mu \mathrm{M}$ HSA were injected by raising the capillary inlet $30-\mathrm{cm}$ height for $2 \mathrm{~min}$ (ca. $0.67 \mu \mathrm{L}$ ). Other conditions are the same as those provided in Figure 1.

proteins, peptides, catecholamines and their metabolites, and heterocyclic aromatic compounds. The inset (B) clearly indicates that the peak for HSA increases in intensity after $0.1 \mu \mathrm{M}$ HSA was spiked into the urine sample. The range of linearity for HSA was $0.01-1.0 \mu \mathrm{M}\left(R^{2}=0.989\right)$. The peak corresponding to HSA is slightly broad, mainly because of relatively low stacking efficiencies for high concentrations of HSA and the overlap of one spike. We note that the peak profile for HSA was sharp and usually no spike occurred around the peak for HSA in the low concentration range $(<0.1 \mu \mathrm{M})$. The sensitivity is relatively low when compared to that of the sample prepared in $10.0 \mathrm{mM}$ TB solution ( $\mathrm{pH} 10.0$ ) because of salt quenching and a low stacking efficiency at high ionic strength. According to a linear regression analysis, we estimate that the concentration of HSA in the urine sample was $0.18 \mu \mathrm{M}$; the normal level for HSA is $<0.29 \mu \mathrm{M}$. We note that the determination of HSA in urine is vital because it is an important marker for assessing renal function. ${ }^{46,47}$ Although we did not identify the peaks corresponding to catecholamines and their metabolites, our results demonstrate that this method is a straightforward one for diagnostic purposes.

The analysis of RBCs (diameter: $7.2-7.9 \mu \mathrm{m}$ ) is of importance because variations in proteins such as hemoglobin $(\mathrm{Hb})$ and CA are related to several diseases, including diabetes, leukemia, hyperthyroid Graves' disease, ${ }^{48,49}$ renal tubular acidosis, ${ }^{50}$ osteoporosis, symmetrical cerebral calcification, and mental retardation. ${ }^{56}$ The concentrations of $\mathrm{Hb}$, CAI, and CAII in single RBCs are ca. 900, 7, and 0.8 amol, respectively. ${ }^{52,53}$ Figure $6 \mathrm{~A}$ demonstrates that the presence of $\mathrm{Hb}$ and $\mathrm{CA}$ in a diluted lysed blood sample could not be detected when the injection was performed at a 30 -cm height for $10 \mathrm{~s}$. We detected two peaks corresponding to $\mathrm{Hb}$ (Figure 6B) when we conducted our proposed stacking method (3-min injection). On the basis of the injection volume (ca. $1.0 \mu \mathrm{L}$ ), we estimate that the amounts of the proteins injected were approximately the same as those in 50 RBCs (see Experimental Section). By applying a standard method (peak area), we estimated the concentrations of $\mathrm{Hb}$ was $45 \mathrm{nM}$, which are in good agreement with a literature result. ${ }^{54}$ Our results clearly suggest that this method is a useful

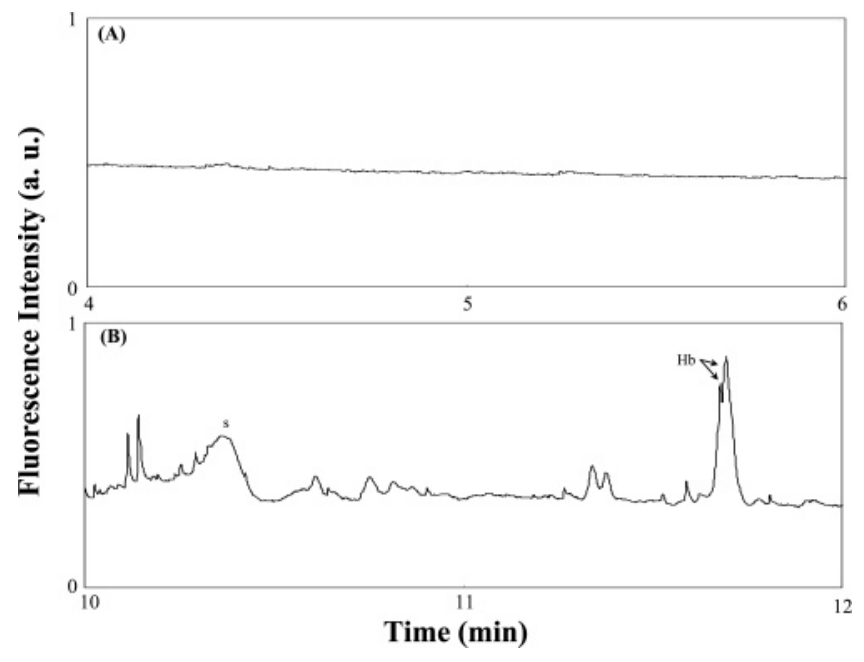

Figure 6. Separation of lysed RBCs samples by CE with LIF detection. Lysed RBCs were prepared in $10.0 \mathrm{mM}$ TB solution $(\mathrm{pH} 10.0)$ containing $0.01 \%$ PEO. The sample was injected by raising the capillary inlet $30-\mathrm{cm}$ height for (A) $10 \mathrm{~s}$ and (B) $3 \mathrm{~min}$ (ca. $1.0 \mu \mathrm{L}$ ). Peak identity: s, system peak. Other conditions are the same as those provided in Figure 1.

one for the analysis of trace amounts of proteins. Because of the limited sensitivity of CE-LIF when using a relatively lowcost UV laser, it is difficult to analyze proteins in single cells, but our results indicate that this method may be useful for the analyses of small numbers of bacteria and/or viruses in various samples when their specific markers are known. We have not conducted such experiments in our laboratory because of safety concerns.

\section{Conclusion}

In this paper, we have demonstrated the analysis of largevolume protein samples (ca. $1.0 \mu \mathrm{L}, 0.1 \mu \mathrm{M}$ ) by using CE-LIF, which has great sensitivity (sub-nM) and efficiency $\left(>10^{5}\right.$ plates $/ \mathrm{m}$ ). We have found that adding SDS or PEO to protein samples is an effective means of minimizing protein adsorption; applying a short plug of $0.2 \%$ SDS is useful for resolving the microheterogeneity of proteins. Our proposed method allows the analysis of urine and blood samples of up to $1.0 \mu \mathrm{L}$, without sample pretreatment, which suggests that this method is robust and rugged and should have great diagnostic applicability. In addition, our method has great potential for proteomics applications that focus on the large-scale identification and quantification of proteins, as well as their localization, modifications, interactions, activities, and, ultimately, their functions. We also demonstrated that the proposed technique can be used for the analysis of large-volume of proteins by CE with UVVis absorption detection. It is our goal to study the proteomics of cells stimulated with drugs by using reversed-phase highperformance liquid chromatography (RPHPLC) in conjunction with our proposed CE method: after the sample has been separated by HPLC in the first dimension, the eluted proteins (large sample volumes) will be subjected directly to CE analysis, which allows on-line concentration and separation of the microheterogeneity of proteins. By applying a short plug of SDS, the detrimental effect of SDS on protein analysis by mass spectrometry should be minimized. Thus, we believe strongly that a greater number of trace amounts of proteins, which may play important biological functions, will be identified when using the two-dimensional RPHPLC-CE method with a dual 
detection system consisting of LIF (or UV-Vis absorption detection) and mass spectrometry.

Acknowledgment. This work was supported by the National Science Council of Taiwan under contracts NSC 942113-M-002-008.

\section{References}

(1) Steiner, S.; Witzmann, F. A. Electrophoresis 2000, 21, 2099-2104

(2) Agaton, C.; Uhlén, M.; Hober, S. Electrophoresis 2004, 25, 12801288.

(3) Patton, W. F. J. Chromatogr. B 1999, 722, 203-223.

(4) Patton, W. F. Electrophoresis 2000, 21, 1123-1144.

(5) Gevaert, K.; Vandekerckhove, J. Electrophoresis 2000, 21, 11451154.

(6) Shen, Y.; Smith, R. D. Electrophoresis 2002, 23, 3106-3124.

(7) Hutterer, K.; Dolník, V. Electrophoresis 2003, 24, 3998-4012.

(8) Lin, Y.-W.; Chiu, T.-C.; Chang, H.-T. J. Chromatogr. B 2003, 793, $37-48$.

(9) Park, Y. H.; Zhang, X.; Rubakhin, S. S.; Sweedler, J. V. Anal. Chem. 1999, 71, 4997-5002.

(10) Tseng, W.-L.; Chang, H.-T. J. Chromatogr. A 2001, 924, 93-101.

(11) Sentellas, S.; Puignou, L.; Galceran, M. T. J. Sep. Sci. 2002, 25, 975-987.

(12) Wang, S.-J.; Tseng, W.-L.; Lin, Y.-W.; Chang, H.-T. J. Chromatogr. A 2002, 979, 261-270.

(13) Britz-McKibbin, P.; Terabe, S. J. Chromatogr. A 2003, 1000, 917934.

(14) Chien R.-L. Electrophoresis 2003, 24, 486-497.

(15) Kim, J.-B.; Terabe, S. J. Pharm. Biomed. Anal. 2003, 30, 16251643.

(16) Urbánek, M.; Krivánková, L.; Bocek, P. Electrophoresis 2003, 24, 466-485.

(17) Wei, W.; Yeung, E. S. Anal. Chem. 2002, 74, 3899-3905.

(18) Chen, J.; Gao, J.; Lee, C. S. J. Proteome Res. 2003, 2, 249-254.

(19) Stutz, H.; Bordin, G.; Rodriguez, A. R. Electrophoresis 2004, 25, 1071-1089.

(20) Kvasnièka, F. Electrophoresis 2003, 24, 860-864.

(21) Mohan, D.; Lee, C. S. Electrophoresis 2002, 23, 3160-3167.

(22) Tseng, W.-L.; Chang, H.-T. Anal. Chem. 2000, 72, 4805-4811.

(23) Chiu, T.-C.; Lin, Y.-W.; Huang, C.-C.; Chrambach, A.; Chang, H.T. Electrophoresis 2003, 24, 1730-1736.

(24) Gomis, D. B.; Junco, S.; Expósito, Y.; Gutiérrez, D. Electrophoresis 2003, 24, 1391-1396.

(25) Nicholas, K. U. K. G.; Forney, C. F.; Paulson, A. T. Phytochem. Anal. 2002, 13, 39-44.

(26) He, Y.; Yeung, E. S. J. Proteome Res. 2002, 1, 273-277.
(27) Tseng, W.-L.; Lin, Y.-W.; Chang, H.-T. Anal. Chem. 2002, 74, 4828-4834.

(28) Trout, A. L.; Prasad, R.; Coffin, D.; DiMartini, A.; Lane, T.; Blessum, C.; Khatter, N.; Landers, J. P. Electrophoresis 2000, 21, 2376-2383.

(29) Simò-Alfonso, E.; Conti, M.; Gelfi, C.; Righetti, P. G. J. Chromatogr., A 1995, 689, 85-96.

(30) Hu, S.; Jiang, J.; Cook, L. M.; Richards, D. P.; Horlick, L.; Wong, B.; Dovichi, N. J. Electrophoresis 2002, 23, 3136-3142.

(31) Horvath, J.; Dolník, V. Electrophoresis 2001, 22, 644-655.

(32) Handbook of Biochemistry and Molecular Biology; Fasman, G. D., Ed.; CRC Press: Boca Raton, FL, 1967.

(33) Tulp, A.; Fernandez-Borja, M.; Verwoerd, D.; Neefjes, J. Electrophoresis 1998, 19, 1288-1293.

(34) Kleindienst, G.; Huber, C. G.; Gjerde, D. T.; Yengoyan, L.; Bonn, G. K. Electrophoresis 1998, 19, 262-269.

(35) Girardet, J.-M.; N'negue, M.-A.; Egito1, A. S.; Campagna, S.; Lagrange, A.; Gaillard, J.-L. Int. Dairy J. 2004, 14, 207-217.

(36) Recio, I.; Pérez-Rodríguez M.-L.; Ramos, M.; Amigo, L. J. Chromatogr. A 1997, 768, 47-56.

(37) Legaz, M. E.; Pedrosa, M. M. J. Chromatogr. A 1996, 719, 159170 .

(38) Kubo, K. Anal. Biochem. 1996, 241, 42-46.

(39) Huang, M.-F.; Hsu, C.-E.; Tseng, W.-L.; Lin, Y.-C.; Chang, H.-T. Electrophoresis 2001, 22, 2281-2290.

(40) Tseng, W.-L.; Chang, H.-T. Electrophoresis 2001, 22, 763-770.

(41) Britz-Mckibbin, P.; Otsuka, K.; Terabe, S. Anal. Chem. 2002, 74, 3736-3743.

(42) Turro, N. J.; Lei, X.-G. Langmuir 1995, 11, 2525-2533.

(43) Pinto, D. M.; Arriaga, E. A.; Craig, D.; Angelova, J.; Sharma, N.; Ahmadzadeh, H.; Dovichi, N. J.; Boulet, C. A. Anal. Chem. 1997, 69, 3015-3021.

(44) Strege, M. A.; Lagu, A. L. Anal. Biochem. 1993, 210, 402-410.

(45) Quirino, J. P.; Terabe, S. Anal. Chem. 1999, 71, 1638-1644.

(46) Thongboonkerd, V.; Mcleish, K. R.; Arthur, J. M.; Klein, J. B. Kidney Int. 2002, 62, 1461-1469.

(47) Marshall, T.; Williams, K. M. Electrophoresis 1998, 19, 1752-1770.

(48) Chiang, W.-L.; Chu, S.-C.; Lai, J.-C.; Yang, S.-F.; Chiou, H.-L.; Hsieh, Y.-S. Clin. Chim. Acta 2001, 314, 195-201.

(49) Yoshida, K. Tohoku J. Exp. Med. 1996, 178, 345-356.

(50) Nagai, R.; Kooh, S. W.; Balfe, J. W.; Fenton, T.; Halperin, M. L. Pediatr. Nephrol. 1997, 11, 633-636.

(51) Aramaki, S.; Yoshida, I.; Yoshino, M.; Kondo, M.; Sato, Y.; Noda, K.; Jo, R.; Okue, A.; Sai, N.; Yamashita, F. J. Inherit. Metab. Dis. 1993, 16, 982-990.

(52) Lindskog, S. Pharmacol. Ther. 1997, 74, 1-20.

(53) Aliakbar, S.; Brown, P. R. Clin. Biochem. 1996, 29, 157-164.

(54) Moini, M.; Demars, S. M.; Huang, H. Anal. Chem. 2002, 74, $3772-3776$.

PR050298Y 